\title{
Effective concrete types with carbon fiber
}

\author{
Vadim Solov'ev ${ }^{1}$, Marsel ' Nurtdinov $^{1}$ and Il'ya Kukhar ${ }^{1, *}$ \\ ${ }^{1}$ Moscow State University of Civil Engineering, Yaroslavskoye sh., 26, Moscow, 129337, Russia
}

\begin{abstract}
The research was conducted in order to determine the effect of the polymer additive on the adhesion between the fiber and the cementsand matrix, since the involvement stage of the composite fiber material directly depends on the adhesion value between these dissimilar components. Throughout the study, the issue at stake was to determine the optimal method for adhesion increasing to assess its effectiveness, and also to carry out an experiment and obtain actual numerical change values of the adhesion to carbon fiber (the assessment was made considering changes of the strength parameters). According to the results of conducted testings, the tensile strength during the bend almost wasn't affected in resin-injected samples with the amount of fiber of 1 and 3\% (increments of 12.7 and $15.7 \%$, respectively). Despite this, the combined application of a resin with the same amount of fiber gave the increments of 34 and $20 \%$, respectively. Conclusions are drawn about the prospects of polymer additives usage in carbon fiber reinforced concrete. The mechanism of increasing the carbon fiber involvement in the composite behavior is considered, the positive effect is confirmed by the study of the chemical processes that arise during the interaction of fiber and water-soluble resin.
\end{abstract}

\section{Introduction}

The increase of the construction volumes, of the erection of buildings and structures, the state trend for technological development of the country and its getting into the top five world economies is impossible in the 21 st century without the integration of original engineering solutions, high-strength materials and innovative technologies. Studying the experience of foreign colleagues and analyzing the current situation considering high-rise buildings erection shows that the future of modern construction will belongs to the use of Ultra High Performance Concrete (UHPC), or especially high-strength concrete with a compressive strength of more than $120 \mathrm{MPa}$.

In order to implement and manufacture such materials, it is necessary to use a complex approach to solve a variety of problems, such as:

- design of concrete composition using mathematical and computer modeling;

- application of high-strength, fractionated, pre-washed aggregates;

- the use of additives and aggregates which compact the structure of concrete as well as chemically strengthen it.

- the use of modern superplasticizers which allow to work with water-cement ratios, bordering with the necessary minimum for the hydration of the binder to flow.

\footnotetext{
* Corresponding author: kucharilya@gmail.com
} 
The paper considers an increment method for the physical and mechanical characteristics of high-strength fine-grained concrete with carbon fiber by injecting a watersoluble epoxy resin DEG-1.

\section{Experimental}

At the first stage of the experimental part, research was carried out to study the effect of the fiber addition on the rheological properties of the mixture, as well as the determination of the optimal mode of integrating the fiber into the composition during the mixing of the components.

Table 1. Results of finding the optimal manufacturing method for a concrete mixture with carbon fiber.

\begin{tabular}{|c|c|c|c|c|c|c|}
\hline \multirow{2}{*}{$\begin{array}{c}\text { Ser. } \\
\text { № }\end{array}$} & \multirow[b]{2}{*}{ Concrete mixture } & \multirow[b]{2}{*}{$\begin{array}{c}\text { Placeability, } \\
\mathrm{cm} / \mathrm{sec}\end{array}$} & \multirow{2}{*}{$\begin{array}{l}\text { Average } \\
\text { density, } \\
\mathrm{kg} / \mathrm{m}^{3}\end{array}$} & \multicolumn{2}{|c|}{ Segregation, \% } & \multirow{2}{*}{$\begin{array}{c}\text { Air } \\
\text { entrainment, } \\
\%\end{array}$} \\
\hline & & & & $\begin{array}{l}\text { Water } \\
\text { gain }\end{array}$ & $\begin{array}{l}\text { Matrix } \\
\text { gain }\end{array}$ & \\
\hline 1 & 2 & 3 & 4 & 5 & 6 & 7 \\
\hline 1 & $\begin{array}{l}\text { Cheque composition } \\
\text { №1 without carbon } \\
\text { fiber }\end{array}$ & $12 /-$ & 2270 & 0.6 & 3.4 & 2.9 \\
\hline 2 & $\begin{array}{l}\text { Fibrous concrete } \\
\text { mixture №1 with } \\
\text { carbon fiber }\end{array}$ & $8 /-$ & 2250 & 0.3 & 1.5 & 3.8 \\
\hline 3 & $\begin{array}{c}\text { Cheque composition } \\
\text { №2 without carbon } \\
\text { fiber }\end{array}$ & $9 /-$ & 2260 & 0.4 & 2.9 & 2.7 \\
\hline 4 & $\begin{array}{c}\text { Fibrous concrete } \\
\text { mixture №2with } \\
\text { carbon fiber }\end{array}$ & $4 /-$ & 2250 & 0.2 & 1.5 & 3.3 \\
\hline 5 & $\begin{array}{l}\text { Cheque composition } \\
\text { №3 without carbon } \\
\text { fiber }\end{array}$ & $2 /-$ & 2280 & 0.3 & 2.2 & 2.5 \\
\hline 6 & $\begin{array}{l}\text { Fibrous concrete } \\
\text { mixture №3 with } \\
\text { carbon fiber }\end{array}$ & $8 /-$ & 2260 & 0.1 & 1.3 & 2.9 \\
\hline 7 & $\begin{array}{l}\text { Cheque composition } \\
\text { №4 without carbon } \\
\text { fiber }\end{array}$ & $-/ 6$ & 2290 & 0.2 & 2.6 & 2.4 \\
\hline 8 & $\begin{array}{c}\text { Fibrous concrete } \\
\text { mixture №4 with } \\
\text { carbon fiber }\end{array}$ & $-/ 7$ & 2280 & 0.1 & 1.1 & 2.5 \\
\hline 9 & $\begin{array}{l}\text { Cheque composition } \\
\text { №5 without carbon } \\
\text { fiber }\end{array}$ & $-/ 15$ & 2310 & 0.2 & 2.2 & 2.3 \\
\hline 10 & $\begin{array}{l}\text { Fibrous concrete } \\
\text { mixture №5 with } \\
\text { carbon fiber }\end{array}$ & $-/ 16$ & 2320 & 0.1 & 1.0 & 2.3 \\
\hline
\end{tabular}

The results are as follows:

1. The most desirable distribution of carbon fiber (CF) can be achieved with the following manufacturing sequence of fibrous concrete mixtures:

- simultaneous loading and mixing of cement, sand and CF for $40 \ldots 50$ seconds; 
- simultaneous loading of ballast stone and water and mixing until a fibrous concrete mixture of the required placeability is obtained.

2. Integrating $\mathrm{CF}$ in concrete mixtures of the placeability grade $\mathrm{P} 2$ and above leads to a grade decrease by one.

3. The integration of CF fibers into concrete mixtures of the placeability P1 and lower does not affect the placeability.

4. The injection of CF fibers into concrete mixtures in an amount of $0.1 \%$ significantly improves their segregation. For the fiber-reinforced concrete mixtures with P1..P3 placeability grades, the values of water and matrix gain are $0.1 \ldots 0.3$ and $1.3 \ldots 1.5 \%$ (the standard values are less than 0.4 and 3, respectively, Table 6, GOST 7473). For a concrete mixture with G1 or G2 placeability grade, the values of water and matrix gain are 0.1 and $1.0 \ldots 1.1 \%$ (the standard values are less than 0.2 and 3, respectively, Table 6, GOST 7473).

5. The integration of CF into the concrete mixture increases the air entrainment by $0.5 \ldots$ $0.9 \%$ for easily workable mixes P1...P3 and for up to $0.1 \%$ for G1 and G2 hard mixes.

Mathematical modeling of the experiment was used to determine the optimum content of fiber in the developed fibrous concrete. The adopted factors (water-cement ratio, geometric properties of fiber and reinforcement ratio) and their variability are given in Table 2. The choice of factors and their variability are based on the results of preliminary research.

Optimization of fiber content is due to the following factors:

- if a certain value is exceeded, the fiber concentration will have a negative effect on the properties of the material;

- high concentration of fiber in the composition should be additionally economically justified due to its high cost.

Table 2. Determination results for the optimal type of manufacturing a concrete mixture with carbon fiber.

\begin{tabular}{|c|c|c|c|c|}
\hline \multirow{2}{*}{ Factors } & \multirow{2}{*}{ Designation } & \multicolumn{3}{|c|}{ Variability levels } \\
\cline { 3 - 5 } & & -1 & 0 & +1 \\
\hline Water-cement ratio, W/C & $\mathrm{X}_{1}$ & 0.56 & 0.48 & 0.40 \\
\hline $\begin{array}{c}\text { Volumetric content of fiber in the concrete } \\
\mu_{\mathrm{v}} \%\end{array}$ & $\mathrm{X}_{2}$ & 0.1 & 0.3 & 0.5 \\
\hline
\end{tabular}

In order to obtain the mathematical model, an orthogonal central composite design of the second order was used.

After the analyze of performed calculations and the obtained results it was concluded that the length of the carbon fiber (the range in question is from 6 to $18 \mathrm{~mm}$ ) does not affect the properties of concrete. The obtained correlation is related to the fact that the optimal ratio of fiber length and its diameter (geometric factor) is 100 . Throughout the study the geometric factor of the carbon fiber was from 330 to 1000 and did not affect the final properties of concrete.

As a result of the calculations, the following mathematical models for designing the heavy types of concrete with carbon fiber were obtained in coded factors as follows:

$$
\begin{gathered}
\mathrm{R}_{\mathrm{c}}=50.2+14.7 \mathrm{X}_{1}-1.1 \mathrm{X}_{2}-2.8 \mathrm{X}_{1}^{2}-2.8 \mathrm{X}_{2}^{2} ; \\
\mathrm{R}_{\mathrm{b}}=8.1+0.9 \mathrm{X}_{1}+0.6 \mathrm{X}_{2}+0.3 \mathrm{X}_{1} \mathrm{X}_{2}+0.5 \mathrm{X}_{1}^{2} ; \\
\rho=2302.9+79.0 \mathrm{X}_{1} \\
\mathrm{w}=3.6-0.8 \mathrm{X}_{1}-0.3 \mathrm{X}_{1}^{2} .
\end{gathered}
$$

Throughout the research carbon fiber FibARM Fiber $\mathrm{C} *$ (further CF) was used according to STO 75969440-020-2011, finished with various chemical substances, with a fiber length of $12 \mathrm{~mm}$ and fiber density of $1.8 \mathrm{~g} / \mathrm{cm} 3$. Cement CEM II / A-Sh 42.5N was used as a binder according to GOST 31108 produced by OAO Holsim (Rus) SM, quarry 
sand with a fineness modulus of 2.5 , a true density of $2.66 \mathrm{~g} / \mathrm{cm} 3$ and a bulk density of $1.58 \mathrm{~g} / \mathrm{cm} 3$. Hardener №620 was used in a 5: 1 ratio for the polymerization of the resin. It was decided to use 1.5 percent of the binder weight as the dosage of resin as this amount is the most optimal. The BASF superplasticizer Glenium Sky 591 was used, the required amount was determined experimentally in order to achieve equal workability of the compositions, to eliminate the effect of placeability of mixtures on testing results. Also microsilica was integrated as a sealing component. Full summary information on the compositions is given in Table 3 .

Table 3. The proportions of materials in the composition of fine-grained concrete types.

\begin{tabular}{|c|c|c|c|c|c|c|c|c|c|}
\hline Composition number & 1 & 2 & 3 & 4 & 5 & 6 & 7 & 8 & 9 \\
\hline Sand & \multicolumn{9}{|c|}{2} \\
\hline Cement & \multicolumn{9}{|c|}{1} \\
\hline $\mathrm{W} / \mathrm{C}$ & 0.35 & 0.31 & 0.29 & 0.35 & 0.31 & 0.29 & 0.35 & 0.31 & 0.29 \\
\hline $\begin{array}{c}\text { Superplasticizer, \% of cement } \\
\text { mass }\end{array}$ & 1.7 & 2.2 & 3.4 & 2.1 & 3.1 & 4.4 & 2.5 & 4.3 & 5.1 \\
\hline Carbon fiber, $\%$ of volume & \multicolumn{3}{|c|}{0} & \multicolumn{3}{|c|}{1} & \multicolumn{3}{|c|}{3} \\
\hline Resin, \% of cement mass & \multirow{2}{*}{\multicolumn{9}{|c|}{0}} \\
\hline Hardener, $\%$ of resin mass & & & & & & & & & \\
\hline Microsilica, $\%$ of cement mass & \multicolumn{9}{|c|}{$5 \%$} \\
\hline Composition number & 10 & 11 & 12 & 13 & 14 & 15 & 16 & 17 & 18 \\
\hline Sand & \multicolumn{9}{|c|}{2} \\
\hline Cement & \multicolumn{9}{|c|}{1} \\
\hline $\mathrm{W} / \mathrm{C}$ & 0.35 & 0.31 & 0.29 & 0.35 & 0.31 & 0.29 & 0.35 & 0.31 & 0.29 \\
\hline $\begin{array}{c}\text { Superplasticizer, \% of cement } \\
\text { mass }\end{array}$ & 1.7 & 2.2 & 3.4 & 2.1 & 3.1 & 4.4 & 2.5 & 4.3 & 5.1 \\
\hline Carbon fiber, $\%$ of volume & \multicolumn{3}{|c|}{1} & \multicolumn{3}{|c|}{3} & \multicolumn{3}{|c|}{0} \\
\hline Resin, $\%$ of cement mass & \multicolumn{9}{|c|}{1.5} \\
\hline Hardener, $\%$ of resin mass & \multicolumn{9}{|c|}{20} \\
\hline Microsilica, $\%$ of cement mass & \multicolumn{9}{|c|}{$5 \%$} \\
\hline
\end{tabular}

Preparation of mixtures, their laying and strength testing of the finished samples was carried out in accordance with GOST 30744-2001.

Testing results and analysis of the received data.

The average strength parameters of the sample series are given in Table 4.

Table 4. Strength parameters of fine grain concrete types.

\begin{tabular}{|c|c|c|c|c|c|c|c|c|c|}
\hline Composition number & 1 & 2 & 3 & 4 & 5 & 6 & 7 & 8 & 9 \\
\hline $\begin{array}{c}\text { Bending strength of the } \\
\text { series, MPa }\end{array}$ & 7.4 & 8.1 & 8.5 & 8.1 & 8.9 & 10.1 & 9 & 9.3 & 9.4 \\
\hline $\begin{array}{c}\text { Compression strength of } \\
\text { the series, MPa }\end{array}$ & 49.8 & 55.1 & 62.7 & 52.8 & 59.2 & 66.1 & 57.4 & 63.7 & 73.8 \\
\hline Composition number & 10 & 11 & 12 & 13 & 14 & 15 & 16 & 17 & 18 \\
\hline $\begin{array}{c}\text { Bending strength of the } \\
\text { series, MPa }\end{array}$ & 8.9 & 11.3 & 12.1 & 9.6 & 9.7 & 9.4 & 7.9 & 9 & 8.1 \\
\hline $\begin{array}{c}\text { Compression strength of } \\
\text { the series, MPa }\end{array}$ & 69.3 & 69.9 & 74.1 & 73 & 75.5 & 78.9 & 71.9 & 85.4 & 74.4 \\
\hline
\end{tabular}

It should be noted that the effect of synergy in increasing the workability of the mixture was significantly manifested in the course of the experiment, when the plasticizing additive and the water-soluble resin were injected simultaneously. 


\section{Evaluation}

For the visual reference of the results the average values of strengths of same compositions, except for W/C (i.e. 1-3, 3-6, 6-9, etc.) were chosen and the increments of strengths in a percentage ratio were compared. The data are given in Table 5.

Table 5. Strength increase of composition groups.

\begin{tabular}{|c|c|c|c|c|c|}
\hline \multicolumn{6}{|c|}{ Strength increment in percentage terms } \\
\hline \multicolumn{3}{|c|}{ Bending strength } & \multicolumn{3}{|c|}{ Compression strength } \\
\hline $\begin{array}{ll}1, \% \\
\text { Fiber, } \%\end{array}$ & 0 & 1.5 & Fiber, $\%$ & 0 & 1.5 \\
\hline 0 & 0 & 4.4 & 0 & 0 & 39.5 \\
\hline 1 & 12.7 & 34 & 1 & 6.3 & 28.1 \\
\hline 3 & 15.7 & 20 & 3 & 16.2 & 36.5 \\
\hline
\end{tabular}

Based on the obtained data, the effect of both bending and compression strength increasing of the cheque composition is strongly pronounced. Particular attention should be given to non-fiber compositions, but with the injection of DEG-1. The increase in bending strength was insignificant $4.4 \%$, which makes it possible to conclude that there is no effect on the strength of the material during tensile stress. However, the compressive strength increased by $39.5 \%$, which indicates an increase in working capacity for compression. A special effect was obtained with the combined use of fiber and a modifying additive. Despite the fact that there is practically no effect on tensile strength during the bend for resin-embedded samples and a low effect at a fiber content of 1 and 3\% (an increase is 12.7 and $15.7 \%$, respectively), when combined with resin with the same content of fiber the growth was 34 and $20 \%$, respectively.

The positive effect of the polymer additive in the composition is due to the fact that the surface of the carbon fibers becomes coated with an epoxy resin while mixing the raw components during the preparation of a fine-grained concrete mixture. This phenomenon can be explained by the fact that carbon fibers are not ideal and contain defects in the form of polar oxygen-containing groups, the origin of which is based on the technology of obtaining fiber by graphitizing acrylonitrile or viscose synthetic fiber. The presence of such defects causes adsorption of the epoxy resin onto the carbon fiber.

As a result, the surface of the fiber is transformed from smooth to rough and, in addition, acquires a certain polarity due to the presence of oxygenated epoxy groups in the composition of epoxy resin macromolecules. The combination of these factors ensures an enhanced adhesion between reinforcing carbon fibers and a cement-sand matrix of concrete.

For the additional assessment of the fiber structure in concrete with the content of the water-soluble DEG-1 resin, additory structural studies were carried out using the focused beam microscope. 
a)

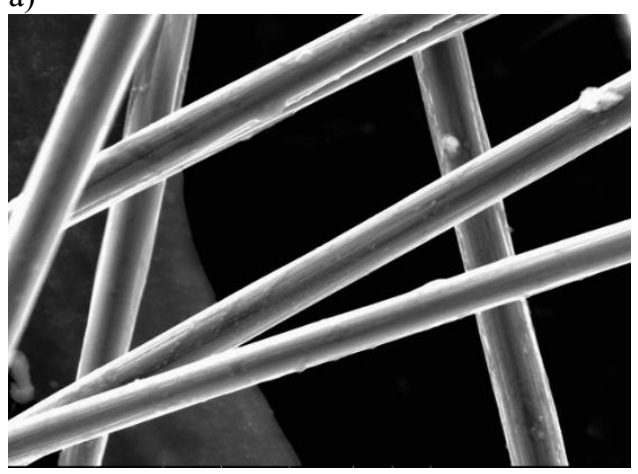

c)

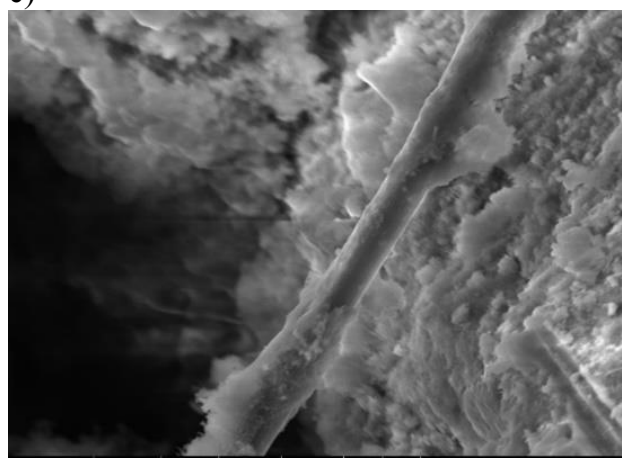

b)

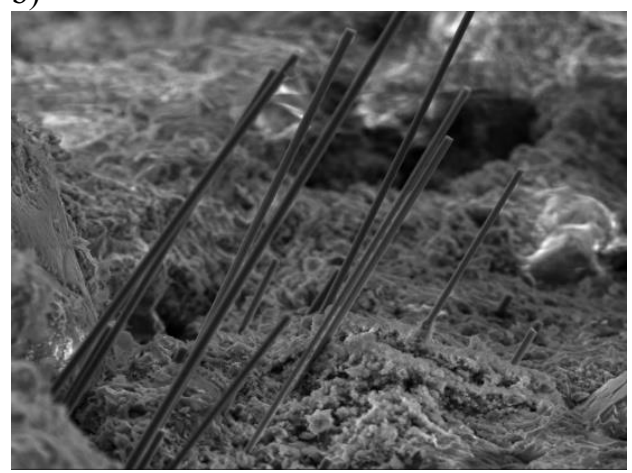

d)

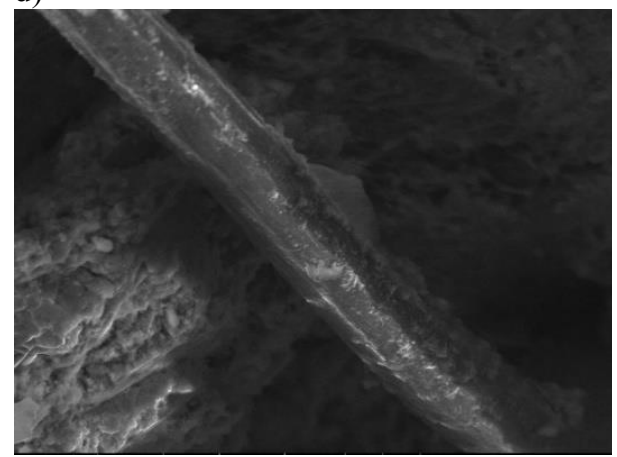

Fig. 3. Microstructure of samples: a) a sample of fiber from the concrete without a polymer additive; b) a sample of fiber from the concrete without a polymer additive; c) a sample of fiber from concrete with a polymer additive; d) a sample of fiber from concrete with a polymer additive.

\section{Conclusions}

1. The use of water-soluble DEG-1 resin as an additive for increasing the engagement of fibrous concrete in the material behavior due to the creation of adhesion between the cement-sand matrix and a fiber is substantiated.

2. Throughout the study, practical recommendations on the integration of carbon fiber into the concrete mixture during its manufacturing to meet the required rheological properties were developed.

3. Optimal contents of the polymer additive and carbon fiber for obtaining concrete with increased strength were established, the increment is up to $50 \%$.

4. The results of studying the microstructure of the fiber have shown that integrating a water-soluble resin into the composition allows using the carbon fiber in concrete more efficiently by creating new growths on the fiber surface.

5. It has been established that the compositions developed throughout the research can be used for various purposes, mainly in purpose-made constructions due to their high physical mechanical and service properties.

\section{References}


1. Y.M. Bazhenov, Tekhnologiya betonov (Izd-vo ASV, Moscow, 2002)

2. V.G. Solov'ev, A.F. Bur'yanov, M.S. Elsuf'eva, Stroitel'nye materialy 3, 18-21 (2014)

3. V.G. Solov'ev, A.F. Bur'yanov, H.-B. Fisher, Stroitel'nye materialy 9, 43-46 (2015)

4. M.S. Elsuf'eva, V.G. Solov'ev, A.F. Bur'yanov, Stroitel'nye materialy 8, 60-63 (2014)

5. A.V. Litvinov, A.A. Shubin, Issledovaniya vliyaniya parametrov dispersnogo armirovaniya na svojstva fibrobetona. Gornyj informacionno-analiticheskij byulleten (2002)

6. M.M. Holmyanskij, Kontakt armatury s betonom (Strojizdat, Moscow, 1981)

7. S.A. Nenahov, Klei. Germetiki. Tekhnologii 4, 2-6 (2007)

8. V.G. Solov'ev, A.F. Bur'yanov, M.R. Nurtdinov, Stroitel'nye materialy 4, 68-71 (2017)

9. V.G. Solov'ev, A.A. Bammatov, M.R. Nurtdinov, I.D. Kuhar', Nauka i biznes: puti razvitiya 5, 55-60 (2018)

10. V.G. Solov'ev, M.R. Nurtdinov, I.D. Kuhar', Perspektivy nauki 6, 53-67 (2018)

11. M. Rangelov, S. Nassiri, L. Haselbach, K. Englund, Construction and Building Materials 126, 875-885 (2016)

12. A. El-Nemr, E.A. Ahmed, C. Barris, B. Benmokrane, Construction and Building Materials 113, 77-89 (2016)

13. N. Banthia, Y. Ohama, Dynamic Tensile Fracture of Carbon Fiber Reinforced Cements (Recent Developments in FRC, Cardiff, 1989)

14. Y. Ohama, M. Amano, M. Endo, Concrete International 7(3), 58-62 (1985) 